DOI : https://doi.org/10.47828/iianaasian.v9i1.54

\title{
Percepatan Reformasi Birokrasi Melalui Budaya Keterbukaan Informasi di Daerah Istimewa Yogyakarta
}

\author{
Dewi Amanatun Suryani ${ }^{1}$, Erni Saharuddin ${ }^{2}$ \\ ${ }^{1}$ Prodi Administrasi Publik FEISHum, Universitas Aisyiyah Yogyakarta, Jalan Siliwangi (Ring \\ Road Barat) No 63 Mlangi Nogotirto Gamping Sleman 55292 , 'Prodi Administrasi Publik \\ FEISHum, Universitas Aisyiyah Yogyakarta, Jalan Siliwangi (Ring Road Barat) No 63 Mlangi \\ Nogotirto Gamping Sleman 55292
}

\section{ARTICLE IN F O}

\author{
Article history : \\ Received 20/02/2021 \\ Received in revised form 25/02/2021 \\ Accepted 30/02/2021
}

\begin{abstract}
Public services in Indonesia have many complaints from the public due to unclear procedures, limited access to information, and inadequate infrastructure. The enactment of the Law on Public Information Disclosure gives the public the right to supervise governance and improve the quality of information management and services within the Public Agency. The DIY Regional Government PPID which has been established since 2013 has not shown good performance. The purpose of this study was to analyze the performance of PPIDs and the factors that influence the acceleration of bureaucratic reform to create a culture of information openness. Performance evaluation is measured based on aspects of productivity, service quality, responsiveness, responsibility, and accountability. Meanwhile, the influencing factors are seen from personal / individual, leadership, team, system, and contextual (situational) factors. This research method uses a qualitative descriptive approach. The data collection technique is done through interviews, observation, and documentation study. An important finding from the performance evaluation results is that PPID productivity and accountability are still low. Meanwhile, factors that hinder performance are limited understanding of PPID, lack of intensity of communication between the Regional Head and Assistant PPIDs and the absence of budget support for PPID. Strategies that need to be carried out include improving the quality of PPID service performance by compiling a community satisfaction index, updating the classification of information regularly, monitoring and evaluation by giving awards and punishment, improving personality and utilizing various social media.
\end{abstract}

Keywords: bureaucratic reform, information disclosure, performance, public service

\begin{abstract}
Abstrak
Pelayanan publik di Indonesia banyak dikeluhkan masyarakat akibat ketidakjelasan prosedur, keterbatasan akses informasi, dan sarana prasarana yang kurang mendukung. Pemberlakuan Undang-Undang Keterbukaan Informasi Publik memberikan hak kepada publik untuk mengawasi penyelenggaraan pemerintahan dan meningkatkan kualitas pengelolaan dan layanan informasi di lingkungan Badan Publik. PPID (Pejabat Pengelola Informasi dan Dokumentasi) Pemda DIY yang telah terbentuk sejak tahun 2013 belum menunjukkan kinerja yang baik. Tujuan penelitian ini adalah menganalisis kinerja PPID dan faktor-faktor yang mempengaruhi dalam upaya percepatan reformasi birokrasi untuk mewujudkan budaya keterbukaan informasi. Evaluasi kinerja diukur berdasarkan
\end{abstract}


aspek produktivitas, kualitas layanan, responsivitas, responsibilitas, dan akuntabilitas. Sedangkan faktor-faktor yang mempengaruhi dilihat dari faktor personal/individu, kepemimpinan, tim, sistem, dan kontekstual (situasional). Metode penelitian ini menggunakan pendekatan deskriptif kualitatif. Teknik pengumpulan data dilakukan melalui wawancara, observasi, dan studi dokumentasi. Temuan penting evaluasi kinerja adalah produktivitas dan akuntabilitas PPID masih rendah. Sedangkan faktor yang sangat menghambat kinerja yaitu keterbatasan pemahaman PPID, kurangnya intensitas komunikasi antara Kepala Daerah dengan PPID Pembantu dan belum adanya dukungan anggaran bagi PPID. Strategi yang perlu dilakukan antara lain meningkatkan kualitas kinerja pelayanan PPID dengan menyusun indeks kepuasan masyarakat, pembaharuan klasifikasi informasi secara berkala, monitoring dan evaluasi dengan pemberian penghargaan dan sanksi, peningkatan personality dan pemanfaatan berbagai media sosial.

Kata kunci: Reformasi Birokrasi, Keterbukaan Informasi, Kinerja, Pelayanan Publik

*)Dewi Amanatun Suryani

E-mail : dewiamanatunsuryani@unisayogya.ac.id

\section{PENDAHULUAN}

Perkembangan jaman di era kebebasan informasi saat ini membawa konsekuensi pada tuntutan masyarakat kepada pemerintah yang semakin dinamis. Hal ini semestinya sejalan dengan reformasi birokrasi khususnya terkait dengan pelayanan akses informasi publik. Hasil temuan yang dilakukan peneliti sebelumnya terhadap implementasi pelaksanaan UndangUndang Keterbukaan Informasi Publik (UU KIP) menunjukkan terdapat keenganan Badan Publik untuk menjalankan pelayanan akses informasi sehingga menimbulkan sengketa informasi publik (Helmi, 2019).

Pemberlakuan UU KIP sejak diundangkan tahun 2008 dengan masa transisi selama dua tahun ternyata belum mampu mewujudkan keterbukaan informasi pada badan publik. Implementasi UU KIP belum berjalan optimal dan efektif. Permasalahan tersebut diantaranya minimnya sosialisasi UU tersebut kepada masyarakat menyebabkan pemahaman mereka terhadap maksud dan tujuan dibuatnya UU keterbukaan informasi masih terbatas. Selain itu rendahnya kemauan dari berbagai badan publik untuk memberikan informasi kepada masyarakat juga turut membuat UU KIP belum mencapai tujuannya (Nurdiansyah, 2016). Sesungguhnya tujuan UU KIP merupakan sarana masyarakat untuk meningkatkan pengawasan terhadap penyelenggaraan berbagai kegiatan pemerintahan, serta sebagai bentuk pertanggungjawaban pemerintah dalam menjalankan amanat yang diberikan oleh masyarakat (Henovanto, Mansur, Ghina, \& Putri, 2020) namun demikian kinerja sektor pelayanan publik masih menjadi sorotan karena berbagai daerah di Indonesia yang ditemukan masih belum cukup baik (Deni Triyanto, 2017). Kasus yang ditemukan oleh pemohon informasi terhadap layanan informasi antara lain ketugasan PPID pada setiap instansi dalam mengelola, menyediakan informasi dan memberikan layanan informasi belum berfungsi secara optimal.

Realita dalam praktek penyelenggaraan layanannya, permohonan informasi disampaikan kepada unit atau bidang lain bukan 
PPID (Grencentia, 2019). Belum optimalnya fungsi PPID di setiap instansi disebabkan rendahnya komitmen sebagian pimpinan Badan Publik untuk melaksanakan UU KIP. Pemahaman akan kewajiban membuka informasi publik belum mengubah mindset ketertutupan yang sudah melekat pada birokrasi berakibat pada tidak terlaksananya atmosfer keterbukaan dengan baik sebagaimana yang diharapkan (Sjoraida 2015). Sumberdaya manusia yang terbatas menyebabkan tugas-tugas pengumpulan informasi terkadang menjadi terbengkalai. Persoalan lain dalam lingkup kelembagaan PPID adalah minimnya anggaran (Marietha, 2017). Tanggung jawab PPID terkait keseluruhan pelayanan informasi publik masih terbatas, kesiapan badan publik, umumnya masih kurang fokus baik dukungan kelembagaan, SDM maupun infrastruktur. Komitmen, regulasi dan anggaran, serta kerjasama, kemitraan, dan koordinasi untuk mencapai efeisiensi dan efektivitas kerja masih mengalami kelemahan(Kenda, 2015).

Berbagai

permasalahan tersebut sampai sekarang masih terjadi sedangkan pemahaman publik semakin meningkat seiring perkembangan situasi dan kemudahan akses informasi dari berbagai sumber. Munculnya istilah keterbukaan diawali dari konsep demokrasi David Beetham yang menyatakan bahwa masyarakat sebagai mayoritas kontrol dan kesetaraan politik. Teori tersebut menunjukkan bahwa dalam konsep demokrasi, masyarakat memiliki hak partisipasi dalam pemerintahan karena memiliki kekuatan dan tidak dapat diintervensi oleh siapapun (Henovanto, 2019. p. 8). Asshidiqie dalam Edwin Nurdiansyah (2016) menyatakan dalam konsep negara hukum yang demokratis, keterbukaan informasi publik merupakan pondasi dalam membangun tata pemerintahan yang baik, yang transparan, terbuka dan partisipasi dalam seluruh proses kenegaraan, termasuk seluruh proses pengelolaan sumber daya publik sejak dari proses pengambilan keputusan, pelaksanaan serta evaluasi.

Peningkatan pemahaman publik terhadap jenis informasi juga berpengaruh pada permintaan informasi. Pada tahun-tahun awal diberlakukannya UU KIP, sengketa lebih banyak terjadi karena tidak dipenuhinya informasi publik yang terbuka seperti informasi yang wajib disediakan dan diumumkan secara berkala. Belakangan, terdapat kecenderungan sengketa yang masuk ke Komisi Informasi merupakan sengketa atas informasi yang dikecualikan. (Zulaikha \& Paribrata, 2017).

Permohonan informasi yang disampaikan pada Pemda DIY sebagai badan publik yang mendapatkan anggaran dari APBN termasuk Dana Keistimewaan tentunya diharapkan mampu mewujudkan pemerintahan yang baik, transparan dan akuntabel serta mencegah terjadinya korupsi. Dalam hal pemberian akses informasi kepada publik sebagaimana amanah UU KIP, Pemda DIY telah membentuk PPID sejak tahun 2013 namun demikian kinerja PPID belum berjalan efektif. Hasil penelitian menunjukkan bahwa komitmen Badan Publik Negara di DIY dalam mematuhi UU KIP masih rendah sehingga upaya mendorong budaya keterbukaan informasi pada Badan Publik perlu ditingkatkan (Dewi Amanatun Suryani, 2017). Peringkat DIY dalam hal keterbukaan informasi di tingkat nasional berdasarkan hasil Monitoring dan Evaluasi yang dilakukan oleh Komisi Informasi 
Pusat pada tahun 2018 masih dikategorikan belum informatif. Sengketa informasi yang diadukan ke Komisi Informasi Daerah (KID) DIY mayoritas adalah informasi yang diklasifikasikan dikecualikan oleh Badan Publik namun dibutuhkan oleh pemohon. Demikian juga dalam hal kemudahan akses informasi yang belum dimiliki oleh setiap PPID melalui website resmi sesuai Permen Kominfo No 5 Tahun 2015. Website diharapkan dapat menjadi media penyampaian informasi baik yang berkaitan dengan aktifitas pemerintahan maupun layanan informasi yang lain (Wanprala, Muallidin, and Kencono 2020)

Upaya percepatan Reformasi Birokasi yang sedang dilakukan untuk memenuhi target pencapaian terbukanya akses informasi sebagai tindak lanjut dari Permenpan RB Nomor 25 Tahun 2020 Tentang Roadmap Reformasi Birokrasi 20202024 dan Perda DIY Nomor 3 Tahun 2018 Tentang RPJMD 2017-2022 menjadi momentum untuk melakukan evaluasi kinerja PPID dalam penyelenggaraan layanan informasi publik dan menganalisis faktor yang berpengaruh pada kinerja PPID dalam mewujudkan budaya keterbukaan informasi dan pencapaian target percepatan reformasi birokrasi. Penelitian ini bertujuan untuk menganalisis kinerja PPID dan faktor-faktor yang mempengaruhi dalam upaya percepatan reformasi birokrasi untuk mewujudkan budaya keterbukaan informasi.

\section{METODE PENELITIAN}

Reformasi Birokrasi di DIY telah dilaksanakan pada 8 area perubahan namun belum semuanya menunjukkan hasil yang signifikan. Salah satu yang mendapat perhatian adalah pelayanan publik khususnya terkait akses informasi. Pemerintah Daerah Daerah Istimewa Yogyakarta (Pemda DIY) membentuk Pejabat Pengelola Informasi dan Dokumentasi (PPID) mengacu pada berbagai peraturan perundangundangan diantaranya UndangUndang Nomor 14 tahun 2008 tentang Keterbukaan Informasi Publik, UU Nomor 25 tahun 2009 tentang Pelayanan Publik, PP 61 Tahun 2010, Permendagri Nomor 3 Tahun 2017 tentang PPID Kementerian Dalam Negeri dan Pemerintahan Daerah, Pergub Nomor 52 Tahun 2018, Keputusan Gubernur Nomor 79 Tahun 2019 tentang PPID, Peraturan Komisi Informasi Nomor 1 Tahun 2010 tentang Standar Layanan Informasi Publik, Peraturan Komisi Informasi Nomor 1 Tahun 2017 tentang Pengklasifikasian Informasi Publik dan Keputusan Gubernur DIY Nomor 124/Kep/2016 tentang Perubahan Kedua atas Peraturan Gubernur DIY Nomor 38/KEP/2010 tentang PPID. Struktur PPID terdiri dari PPID Utama yang melekat pada Dinas Kominfo sebagai perangkat daerah yang membidangi urusan pemerintahan di bidang komunikasi dan informatika dan PPID Pembantu yang melekat pada Pejabat Eselon III yang membidangi fungsi pengelolaan data dan informasi pada tiap perangkat daerah atau kepala sub bagian yang membidangi fungsi pengelolaan data dan informasi. Penelitian ini mengkaji upaya percepatan reformasi birokrasi dengan melakukan evaluasi kinerja PPID.

Pengertian evaluasi (Tullah and Hanafri 2014) adalah suatu proses untuk menyediakan informasi tentang sejauh mana suatu kegiatan tertentu telah dicapai, bagaimana perbedaan pencapaian itu dengan standar tertentu untuk mengetahui apakah ada selisih diantara keduanya, 
serta bagaimana manfaat yang telah dikerjakan itu bila dibandingkan dengan harapan-harapan yang ingin diperoleh. Sedangkan pengertian kinerja adalah prestasi kerja yang merupakan hasil dari implementasi rencana kerja yang dibuat oleh suatu institusi yang dilaksanakan oleh pimpinan dan karyawan (SDM) yang bekerja di institusi itu baik pemerintah maupun perusahaan (bisnis) untuk mencapai tujuan organisasi (Abdullah 2014). Pengertian kinerja juga diartikan kesediaan seseorang atau kelompok orang untuk melakukan sesuatu kegiatan dan menyempurnakannya sesuai dengan tanggung jawabnya dengan hasil seperti yang diharapkan (Nursam 2017).

$\mathrm{Wu}$ dan Hung menyampaikan bahwa evaluasi kinerja menjadi bagian dari manajemen dan sistem kontrol yang membantu organisasi untuk secara efektif mengelola sumber daya dalam kaitannya dengan tujuan organisasi (Tunggul, Isnanto, and Nurhayati 2016). Sistem manajemen kinerja memungkinkan organisasi untuk merencanakan, mengontrol, mengevaluasi dan mengatur kinerja (mengenai keluaran dan hasil). Proses tersebut dilakukan dengan mempromosikan tujuan bersama dan memperkenalkan kontrol berbasis berkelanjutan juga memungkinkan organisasi untuk meningkatkan budaya, sistem pelaporan dan produktivitas sumberdaya (West and Blackman 2015). Dengan demikian evaluasi kinerja bermanfaat dalam mengelola sumberdaya dan menciptakan budaya kerja yang optimal, efektif dan efisien.

Mengacu pada konsep yang dikemukakan Dwiyanto (Wardana and Meiwanda 2017) indikatorindikator kinerja meliputi : a) Produktivitas (mengukur tingkat efisiensi, efektivitas pelayanan, dan tingkat pelayanan publik dalam rangka mencapai hasil yang diharapkan); b) Kualitas layanan (mengukur kepuasan masyarakat terhadap layanan yang diberikan); c) Responsivitas (kemampuan organisasi untuk mengenali kebutuhan masyarakat, menyusun agenda dan prioritas pelayanan, serta mengembangkan program-program pelayanan publik sesuai dengan kebutuhan/ aspirasi masyarakat); d) Responsibilitas menjelaskan/ mengukur kesesuaian pelaksanaan kegiatan organisasi publik yang dilakukan dengan prinsip-prinsip administrasi yang benar atau sesuai dengan kebijakan organisasi); e) Akuntabilitas (menunjuk pada seberapa besar kebijakan dan kegiatan organisasi publik tunduk pada para pejabat politik yang dipilih oleh rakyat dan konsisten dengan kehendak masyarakat banyak.

Laporan hasil pemeringkatan KID menyebutkan terdapat 2 (dua) PPID Pembantu yang mendapatkan peringkat terbaik dari tiga terbaik yaitu Dinas Komunikasi dan Informatika (Diskominfo) dan Badan Pemberdayaan Perempuan dan Masyarakat yang sekarang menjadi Dinas Pemberdayaan Perempuan, Perlindungan Anak, dan Pengendalian Penduduk (DP3AP2) sedangkan PPID berkinerja terburuk dalam pelayanan informasi publik diantaranya yaitu Badan Pendidikan dan Pelatihan (Bandiklat) dan Dinas Lingkungan Hidup dan Kehutanan (DLHK).

Metode penelitian ini menggunakan pendekatan deskriptif kualitatif. Informan dalam penelitian ini terdiri dari 4 (empat) PPID pembantu yang mewakili keseluruhan PPID dengan alasan 2 (dua) PPID merupakan tebaik dan dijadikan role models dan 2 (dua) berikutnya termasuk kategori 
terburuk selama dua tahun berturutturut berdasarkan pemeringkatan yang dilakukan oleh Komisi Informasi Daerah (KID) DIY tahun 2018. Prosedur dalam pengumpulan data penelitian antara lain dilakukan melalui Observasi dengan merekam/mencatat - baik dengan cara terstruktur maupun semistruktur, wawancara mendalam, mempelajari dokumen-dokumen berupa laporan dan publikasi melalui website maupun data pendukung di masing-masing PPID. Analisis dan interprestasi data dilakukan dengan langkah-langkah mengolah dan mempersiapkan data untuk dianalisis, membaca keseluruhan data yang diperoleh, dan melakukan coding semua data. Sedangkan keabsahan data dilakukan melalui triangulasi sumber sebagai teknik keabsahan yang digunakan peneliti. Triangulasi merupakan proses dengan cara pengecekan data-data yang diberikan satu narasumber kepada narasumber lainnya.

\section{HASIL DAN DISKUSI/ANALISIS}

Hasil pengukuran kinerja PPID dalam memberikan pelayanan informasi kepada publik dengan mengacu konsep diatas adalah sebagai berikut:

a) Produktivitas. Kinerja PPID Pemda DIY dalam hal pelayanan informasi dinilai cukup. Hal ini dapat dilihat dari hasil penilaian peringkat Keterbukaan Informasi Publik yang dilakukan oleh Komisi Informasi Pusat. Pada Tahun 2016 Pemda DIY tidak masuk dalam 10 besar Provinsi yang terbuka. Pada tahun 2017 masuk pada kategori cukup infomatif, dan tahun 2018 masuk kategori menuju informatif. Meskipun mengalami kenaikan peringkat namun ditingkat PPID Pembantu belum dilengkapi standar layanan informasi seperti SOP, Website, dan anggran khusus PPID. Hasil temuan lapangan menunjukkan bahwa tidak semua informasi mudah dicari dalam mesin pencarian website. Detail informasi yang ditampilkan pada website tidak mudah diakses oleh publik atau masyarakat. Pemohon informasi harus terlebih dahulu meminta bantuan dari PPID untuk mengaksesnya. Keberadaan website merupakan kewajiban Badan Publik sesuai Pasal 7 UU KIP dan Pasal 20 Perki 1 Tahun 2010. Peneliti menemukan terdapat PPID yang tidak memiliki website resmi yang dapat diakses. langsung oleh masyarakat. Bandiklat memiliki website dengan alamat http://imt@jogjaprov.go.id yang hanya dapat diakses secara terbatas bagi Aparatur Sipil Negara. Pembatasan akses informasi berdasarkan penuturan PPID Bandiklat dilakukan karena posisinya sebagai tempat penyelenggaraan pendidikan dan pelatihan dimana input SDM yang akan dididik dan dilatih berasal dari data di Badan Kepegawaian Daerah (BKD). Peserta terbatas pada ASN bukan masyarakat umum. Pemahaman mengenai keterbatasan layanan informasi ini juga hampir sama dengan PPID DLHK dimana pelayanan pubik secara langsung dilakukan oleh UPTD sedangkan Dinas 
menempatkan posisi sebagai pengambil kebijakan umum. Oleh karena itu dalam kategorisasi PPID perlu ditinjau ulang terkait OPD (Organisasi Perangkat Daerah) yang secara langsung melayani masyarakat maupun yang tidak termasuk ketugasan PPID UPTD.

Pasal 4 UU KIP menyebutkan Badan Publik wajib melakukan evaluasi dan pengawasan terhadap pelaksanaan layanan Informasi Publik pada instansinya. Evaluasi internal ini belum pernah dilakukan oleh PPID demikian juga infografis tentang jumlah pemohon informasi dan indeks kepuasaan masyarakat (IKM) terhadap layanan informasi. IKM yang dimunculkan dalam website masing-masing OPD merupakan nilai layanan umum yang hasilnya baik namun belum mendekati sempurna.

Tabel 1.

Indeks Kepuasan Masyarakat

\begin{tabular}{|l|l|l|}
\hline NO & Nama OPD & Nilai \\
\hline 1 & Diskominfo & 84,36 \\
\hline 2 & DP3AP2 & 83 \\
\hline 3 & DLHK & 87,76 \\
\hline 4 & Bandiklat & 79,76 \\
\hline
\end{tabular}

Sumber: Website OPD Pemda DIY dan Dokumentasi Bandiklat

Hasil penilaian masyarakat tersebut diatas menunjukkan bahwa kinerja keempat OPD berjalan efektif. Penilaian persepsi masyarakat terhadap kinerja Bandiklat sebanding dengan hasil penilaian keterbukaan informasi yang dilakukan oleh KID.
Dari hasil penilian tersebut maka PPID Utama diharapkan lebih banyak melakukan pendampingan agar pelayanan semakin memuaskan. Setiap tahun PPID berkewajiban mengumumkan layanan informasi yang terdiri dari jumlah permintaan informasi yang diterima, waktu yang diperlukan dalam memenuhi setiap permintaan informasi, jumlah pemberian dan penolakan permintaan informasi, dan/ atau penolakan permintaan informasi.

Upaya yang telah dilakukan dalam menunjang produktivitas kinerja diantaranya penyediaan sarana dan prasarana, pemanfaatan sarana dan prasarana dengan memberikan berbagai fasilitas yang dapat diakses oleh publik baik secara langsung maupun melalui daring termasuk penyediaan kursi roda dan alat bantu dengar bagi difabel dan menjunjung etika pelayanan. Serta pemanfaatan media sosial secara aktif.

b) Kualitas layanan. Berdasarkan Peraturan Menteri Pendayagunaan Aparatur Negara dan Reformasi Birokrasi Republik Indonesia Nomor 15 Tahun 2014, komponen standar pelayanan yang terkait dengan proses penyampaian pelayanan meliputi Persyaratan, prosedur, jangka waktu pelayanan, biaya/tarif, produk pelayanan, dan penanganan pengaduan . Dalam hal kualitas yang diberikan oleh PPID Utama dan PPID pembantu termasuk baik. Hal ini ditandai dengan kemudahan pemohon informasi menyampaikan permohonan. Petugas memberikan pelayanan dengan baik dan ramah. Koordinasi antar PPID dalam 
memberikan layanan berjalan

lancar

dengan

diselengarakannya pertemuan setiap tiga bulan sekali termasuk koordinasi internal di masing-masing PPID Pembantu bahkan dilakukan setiap saat jika terdapat halhal yang harus segera ditanggapi. PPID Pembantu segera menghubungi PPID Utama untuk meminta saran terhadap permohonan informasi yang disampaikan langsung kepadanya. Jangka waktu layanan juga memenuhi standar yaitu sebelum 10 hari kerja sesuai batas waktu PPID menanggapi. Persyaratan bagi pemohon informasi sederhana, pemohon dapat langsung mengisi surat permohonan yang tersedia di website atau mengisi blangko permohonan jika datang lagsung ke PPID. Pemohon tidak dikenakan biaya dalam memperoleh informasi.

c) Responsivitas, dapat diketahui dari cepat tanggapnya PLID dalam merespon kebutuhan informasi yang dimohonkan, menanggapi permohon dan menjawab tanggapan keberatan yang diajukan oleh pemohon informasi. Respon yang diberikan dalam pelayanan adalah merupakan bentuk dari kewajiban birokrasi dan pengabaian terhadap hal tersebut akan berdampak pada kekecewaan yang berujung pada krisis kepercayaan kepada pemerintah. Permohonan informasi yang tidak ditanggapi sesuai dengan jangka waktu, kepuasan pemohon, dan penolakan disebabkan informasi yang dimohonkan merupakan informasi yang dikecualikan berujung pada sengketa informasi. Sengketa yang diadukan masyarakat terhadap Pemda DIY disidang oleh KID DIY dalam perkara informasi pengadaan barang dan jasa pada tahun 2018. Hal ini terjadi sebab informasi yang diminta oleh pemohon termasuk informasi yang dikecualikan sedangkan hasil putusan Komisi Informasi dengan putusan Nomor 006/IX/KIDDIY-PS/2018 yang berisi mengabulkan sebagian informasi yang dimohonkan oleh pemohon terkait dokumen lelang pengadaan barang dan jasa pada Badan Perpustakaan dan Arsip Daerah pemda DIY (http://komisi-

informasi@jogjaprov.go.id)

Berdasarkan putusan tersbut maka PPID Pemda DIY wajib memperbaharui Daftar Informasi yang dikecualikan (DIK) secara terperinci dan memilah kembali data dan dokumen berdasarkan klasifikasi informasi.

d) Responsibilitas, menjelaskan apakah pelaksanaan kegiatan pelayanan itu dilakukan sesuai dengan prinsip -prinsip administrasi yang benar atau sesuai dengan kebijaksanaan organisasi dalam pelayanan baik yang implisit maupun eksplisit (Paris 2014) yang dapat diukur melalui adanya sanksi yang tegas bagi PLID yang melalaikan tugas dalam memberikan pelayanan informasi maupun sanksi bagi petugas yang melanggar peraturan/disiplin. Ketentuan ini mengacu pada Pasal 52-56 
UU KIP dimana Badan Publik dapat dikenai sanksi pidana apabila tidak menyediakan informasi, menghilangkan atau merusak dokumen, memberikan informasi yang seharusnya dirahasiakan, membuat informasi yang tidak benar yang merugikan orang lain. Hasil wawancara kepada PPID Utama dan PPID pembantu menyatakan bahwa Selama kurun waktu 20172019 tidak ada PPID yang melanggar aturan sehingga dalam hal ini responsibilitas PPID dapat dikatakan baik dan berpengaruh terhadap kinerja PPID.

e) Akuntabilitas, yaitu adanya pembagian tugas dan wewenang serta tanggung jawab dalam pelaksanaan PPID. Dikaitkan dengan pelayanan publik, akuntabilitas merupakan bentuk pertanggungjawaban pemberi layanan publik dalam melaksanakan tugas pokok dan fungsinya (Grescentia. T 2019). Berdasarkan hasil wawancara dengan PPID Pembantu hanya Diskominfo yang telah membuat SK internal tentang PPID. Pembagian tugas dan wewenang sudah dilakukan namun demikian dalam praktek pelayanan tidak semua dapat dilaksanakan mengingat skala prioritas pekerjaan setiap OPD berbeda-beda. Hal ini dapat mempengaruhi kinerja PPID dalam memberikan layanan informasi. Kontrol eksternal terhadap kinerja PPID dilakukan oleh KID DIY melalui kegiatan monitoring dan evaluasi implementasi keterbukaan infomasi pada Badan Publik Negara (PPID Pemda DIY). Selama kurun waktu tiga tahun terakhir dapat dilihat dari tabel dibawah ini:

Tabel 2.

\section{Hasil Monitoring dan Evaluasi}

PPID Pemda DIY

\begin{tabular}{|c|c|c|c|c|}
\hline NO & Uraian & 2017 & 2018 & 2019 \\
\hline 1. & $\begin{array}{l}\text { Tingkat } \\
\text { Pengem } \\
\text { balian } \\
\text { SAQ }\end{array}$ & $\begin{array}{l}71 \% \\
(27 \text { dari } \\
38)\end{array}$ & $\begin{array}{l}73 \% \\
(27 \text { dari } \\
37)\end{array}$ & $\begin{array}{l}84 \% \\
\text { (32 dari } \\
38)\end{array}$ \\
\hline 2. & $\begin{array}{l}\text { Hasil } \\
\text { Pemeri } \\
\text { ngkatan } \\
\text { Terbaik }\end{array}$ & $\begin{array}{l}\text { 1. Disko } \\
\text { minfo } \\
(79,2 \\
5) \\
\text { 2. } \\
\text { Bandi } \\
\text { klat } \\
(67,0 \\
5) \\
\text { 3. } \\
\begin{array}{c}\text { BKD } \\
(59, \\
82)\end{array}\end{array}$ & 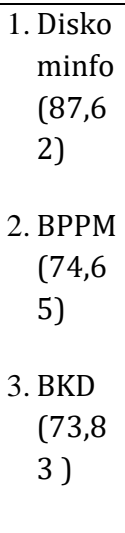 & $\begin{array}{l}\text { 1. Disko } \\
\text { minfo } \\
(92,5 \\
2) \\
\text { 2. DP3A } \\
\text { PP } \\
(87,3 \\
4) \\
\text { 3. BKD } \\
\text { (81,9 } \\
\text { 9) }\end{array}$ \\
\hline
\end{tabular}

Sumber : Hasil Monev KID diolah

Berdasarkan tabel diatas dapat terlihat bahwa tingkat keterbukaan informasi di DIY terjadi peningkatan yang cukup signifikan namun masih belum sangat baik. Jumlah PPID yang menyampaikan hasil Assesment keterbukaan informasi belum mencapai 100\%. Hal ini menandakan bahwa akuntabilitas kinerja PPID belum optimal.

Budaya keterbukaan merupakan bagian dari kemajuan suatu masyarakat. Budaya masyarakat yang tinggi dalam merespon implementasi UU KIP menjadi modal budaya yang dapat dikembangkan untuk memasyarakatkan keterbukaan informasi publik dan kesadaran masyarakat lokal memanfaatkan informasi yang ada (Kenda 2015). Implementasi keterbukaan informasi 
akan mewujudkan budaya masyarakat informatif yang dapat digunakan untuk mengembangkan ilmu pengetahun dan mencerdaskan kehidupan bangsa. Indonesia merupakan negara hukum dengan sistem demokrasi. Sebagai negara hukum demokrasi dimana pelaksanakan sistem kenegaraannya berdasarkan amanat rakyat, maka sudah sewajarnya dan bahkan merupakan hak rakyat untuk mengetahui informasi kinerja penyelenggaraan negara dan/atau pemerintahan (Retnowati 2012). Penyelenggaraan pelayanan informasi menjadi bagian dalam pemenuhan hak rakyat atas informasi. Sebagai amanah UU KIP, Pemda DIY membentuk PPID. Agar implementasi budaya keterbukaan informasi dapat terwujud setidaknya terdapat empat instrumen yang harus disiapkan yakni instrumen yuridis, instrumen materiil, personil atau kepegawaian (sumberdaya manusia) dan instrumen keuangan atau pembiayaan. Kesiapan bagi personil atau pegawai (sumberdaya manusia) baik dari sisi integritas, moral, budaya ataupun kesadaran untuk melayani, serta kemampuan (skill). Keterbukaan informasi merupakan salah satu prinsip yang penting dari good governance, yang dapat membantu untuk mewujudkan penyelenggaraan pelayanan publik yang baik dan prima (Susila Wibawa 2019).

Faktor-faktor yang mempengaruhi kinerja PPID dalam Mewujudkan Budaya Keterbukaan Informasi Publik di DIY sebagai berikut:

a) faktor personal/individual yang meliputi: pengetahuan, ketrampilan (skill), kemampuan, kepercayaan diri, motivasi, dan komitmen yang dimiliki oleh setiap individu. Tingkat pemahaman PPID Bandiklat dan DLHK tentang pengklasifikasian informasi masih terbatas. Berdasarkan hasil pengamatan dan wawancara menujukkan bahwa tingkat personality pada PPID DLHK dan Bandiklat dinilai cukup. PPID DLHK dalam wawancara menyebutkan bahwa retensi informasi yang dikecualikan tidak terbatas. Demikian juga PPID Bandiklat yang menyatakan bahwa informasi tentang pelatihan dan pendidikan hanya terbatas pada ASN yang ditentukan oleh BKD sehingga hak atas akses informasi pelatihan masih belum dapat memenuhi asas keterbukaan. Kendala yang juga dihadapi adalah keterbatasan latar belakang pendidikan staf PPID.

b) faktor kepemimpinan, meliputi: kualitas dalam memberikan dorongan, semangat, arahan, dan dukungan yang diberikan atasan PPID. Dari hasil wawancara dengan PPID Pembantu menyatakan bahwa pemimpin sangat perhatian dengan memberikan arahan dan koordinasi secara intensif terhadap pemecahan masalah yang terjadi. Namun demikian di tingkat Pengambil kebijakan (Gubernur dan Atasan PPID) kurang terjalin komunikasi secara langsung dengan PPID Pembantu. Komunikasi menjadi problem dalam implementasi keterbukaan informasi di beberapa daerah pada umumnya dikarenakan koordinasi yang lemah. Indikator kurangnya komunikasi antara lain ketiadaan SOP. Akibatnya komunikasi internal menjadi terhambat (Noor 2019).

c) faktor tim, meliputi: kualitas dukungan dan semangat yang 
diberikan oleh rekan dalam satu tim, kepercayaan terhadap sesama anggota tim, kekompakan dan keeratan anggota tim. Hasil penelitian menunjukkan bahwa keterbatasan jumlah SDM mempererat dukungan dan semangat didalam tim. Koordinasi dilakukan secara intensif dengan memanfaatkan teknologi informasi. Untuk mempererat tim dilaksanakan forum koordinasi antar PPID. Beban tugas sebagai PPID sekaligus pelaksana tugas untuk mendukung program OPD diantisipasi dengan pembagian tugas melalui penjadwalan dan saling mengingatkan untuk selalu menyediakan informasi yang harus disampaikan setiap hari atau mengecek permohonan informasi yang disampaikan melalui berbagai media baik daring maupun luring.

d) faktor sistem, meliputi: sistem kerja, fasilitas kerja atau infrastruktur yang diberikan oleh organisasi, proses organisasi, dan kultur kinerja dalam organisasi terlihat masih terbatas terutama dalam fasilitas kerja dan infrastuktur dikarenakan tidak ada anggaran khusus untuk PPID. Dalam hal media penyampaian informasi khususnya keberadaan website menjadi media yang paling efektif sehingga pembatasan akses website pada Bandiklat menjadi hambatan dalam mewujudkan budaya keterbukaan.

e) faktor kontekstual (situasional), meliputi: tekanan dan perubahan lingkungan eksternal dan internal. Faktor Situasional baik politik, ekonomi dan sosial sangat mempengaruhi perilaku semua pihak dalam mengimplementasikan kebijakan.
James P. Lester \& Joseph Stewart (2000;104) dalam (Marietha 2017) menunjukkan bahwa proses implementasi kebijakan tidak hanya menyangkut perilaku badan-badan administratif yang bertanggung jawab untuk melaksanakan program dan menimbulkan ketaatan pada diri targer group, melainkan menyangkut lingkaran kekuatan politik, ekonomi, dan sosial yang langsung atau tidak dapat mempengaruhi perilaku dari semua pihak yang terlibat, dan pada akhirnya membawa konsekuensi logis terhadap dampak baik yang diharapkan maupun dampak yang tidak diharapkan. Pandemi Covid 19 membawa dampak pada prosedur layanan informasi dengan tata aturan baru dan mengutamakan pelayanan publik melalui daring. Hal ini pada awalnya membuat tidak nyaman bagi masyarakat yang lebih senang bertemu langsung. Untuk mengatasinya PPID Utama telah mengembangkan sistem informasi berbasis website dan media sosial seperti twitter, facebook, dan instagram untuk menjangkau publik di segala lapisan baik dari usia maupun latar belakang masyarakat. Sedangkan untuk menjangkau masyarakat secara lebih luas dikembangkan aplikasi berbasis WAG. Dalam pelaksanaannya di setiap PPID Pembantu sudah ada penghubung untuk memberikan pelayanan informasi publik. Konteks situasional yang juga berpengaruh pada kinerja PPID juga berasal dari meningkatnya kesadaran masyarakat untuk mengakses informasi. Oleh karena itu Pemda DIY harus pro aktif menyediakan informasi dan 
memperbaharui informasi berdasarkan uji konsekuensi yang teliti, seksama dan hati-hati agar tidak terjadi lagi sengketa yang sama di tahun-tahun mendatang.

\section{KESIMPULAN}

Kesimpulan dari hasil penelitian evaluasi kinerja PPID Pemda DIY dalam mewujudkan budaya keterbukaan informasi publik belum optimal terutama dalam hal akuntabilitas dan produktivitas. Faktor yang berpengaruh dan perlu lebih banyak diperhatikan adalah faktor personal, faktor sistem terutama fasilitas kerja dan infrastruktur, dan faktor kontekstual dalam memenuhi kebutuhan informasi publik.

Rekomendasi dari hasil penelitian ini sebagai upaya percepatan reformasi birokrasi dalam pelayanan akses informasi dan acuan penelitian berikutnya adalah :

1. PPID diharapkan memenuhi standar layanan informasi, melakukan pemilahan OPD berdasarkan jenis layanan (langsung atau tidak) kepada masyarakat, mengukur indeks kepuasan masyarakat dalam pelayanan informasi dan menyampaikan laporan layanan informasi kepada publik

2. PPID memperbaharui klasifikasi informasi secara berkala.

3. PPID melakukan monitoring dan evaluasi secara berkala diikuti pemberian penghargaan dan sanksi bagi OPD yang tidak terbuka.

4. PPID melakukan Bimtek untuk peningkatan kapasitas dan penambahan SDM yang memiliki latar belakang pendidikan ilmu komunikasi, hukum, dan administrasi publik. Tenaga bantu ini dapat berasal dari kegiatan magang atau pengabdian dari institusi pendidikan.

5. Gubernur selaku Kepala Daerah dan Sekda sebagai atasan PPID membangun komunikasi yang lebih intensif dengan PPID Pembantu dan memberikan dukungan melalui Surat Keputusan agar PPID semakin berkomitmen dalam melaksanakan tugas.

6. Forum koordinasi antar PPID Pembantu lebih diintensifkan untuk mensinergikan informasi antar PPID yang saling berkaitan untuk mencegah disinformasi.

7. Infrastruktur dan fasilitas kerja dipenuhi dengan penganggaran khusus PPID.

8. Sosialisasi dan edukasi pada OPD dan masyarakat perlu ditingkatkan melalui berbagai media untuk mewujudkan budaya masyarakat informatif dan mendukung terwujudnya percepatan reformasi birokrasi.

\section{PENGHARGAAN}

Ucapan terima kasih disampaikan kepada :

1. Direktorat Riset dan Pengabdian Masyarakat (DRPM) Direktorat Jenderal Penguatan Riset dan Pengembangan Kemenristekdikti berdasarkan Surat Keputusan Nomor 26/E1/KPT/2020 tanggal 4 Mei 2020 dan Perjanjian/ Kontrak Nomor 081/SP2H/AMD/LT/DRPM/2020 tanggal 20 Mei 2020, Nomor Amandemen Kontrak Tunggal antara LLDIKTI dengan UNISA Yogyakarta nomor 625.17/LL5/PG/2020 tanggal 2 Juni 2020 dan Nomor kontrak Amandemen Kontrak tunggal 
antara UNISA Yogyakarta dengan ketua Peneliti nomor 13/LPPM/UNISA/VI/2020 tanggal 8 Juni 2020 tentang Penelitian Dosen Pemula.

2. Rektor Universitas Aisyiyah Yogyakarta dan LPPM UNISA Yogyakarta yang telah memberikan dukungan dalam penelitian ini.

\section{REFERENSI}

Abdullah, M. Ma'ruf. 2014. Perpustakaan Nasional RI Manajemen Dan Evaluasi Kinerja Karyawan.

Deni Triyanto. 2017. “Analisis Kinerja Organisasi Dalam Mewujudkan Pelayanan Prima Kepada Masyarakat (Studi Pada Kantor Badan Pelayanan Perizinan Terpadu Kota Semarang)." Mimbar Jurnal Penelitian Sosial dan Politik 6(4): 6-13.

Dewi Amanatun Suryani. 2017. "Mewujudkan Good Governance Badan Publik Negara Di Daerah Istimewa Yogyakarta Melalui Keterbukaan Informasi Publik." Spirit Publik Volume 12, Nomor 1 Halaman 35-44 12(April): 35-44. Grescentia. T, V. 2019. "Keterbukaan Informasi Dalam Pelayanan Perizinan Di Dinas Perizinan Dan Penanaman Modal Daerah Istimewa Yogyakarta." JSPG: Journal of Social Politics and Governance 1(2): 66-80.

Helmi, Rahmadhona Fitri. 2019. "Penyelesaian Sengketa Informasi Publik di Komisi Informasi Provinsi Sumatera Barat." JESS (Journal of Education on Social Science).

Henovanto, Khansa, Muhammad
Mansur, Siti Ghina, and Zahra Karyna Putri. 2020. "Analisis Pencapaian PPID Provinsi DKI Jakarta Dalam Meraih Penghargaan Keterbukaan Informasi Publik Tahun 2019." Jurnal Noken: Ilmu-Ilmu Sosial 5(1): 1-14.

Kádárová, Jaroslava, Michaela Durkáčová, and Lenka Kalafusová. 2014. "Innovative Approaches to the Modification of BSC Model." Procedia - Social and Behavioral Sciences.

Kenda, Ndoheba. 2015. "Implementasi Pejabat Pengelola Informasi Dan DokuImplementation of Information and Documantation Of-." Jurnal Penelitian Komunikasi dan Opini Publik 19(3): 165-86.

Marietha, Sri Rezeki. 2017. "Keterbukaan Informasi Publik Pemerintah Provinsi Kalimantan Timur." (April): 68-77.

Noor, Muhammad Usman. 2019. "Inisiasi Masyarakat Informasi Di Indonesia Melalui Implementasi Keterbukaan Informasi Publik: Satu Dekade Undang-Undang Keterbukaan Informasi Publik." Khizanah al-Hikmah : Jurnal Ilmu Perpustakaan, Informasi, dan Kearsipan 7(1): 11.

Nurdiansyah, $\quad$ Edwin. 2016. "Keterbukaan Informasi Publik Sebagai Upaya Mewujudkan Transparansi Bagi Masyarakat." Bhineka Tunggal Ika 3(2): 14751.

Nursam, Nasrullah. 2017. "Manajemen Kinerja." Kelola: Journal of Islamic Education Management.

Paris, Yusran. 2014. "Pengaruh Pelayanan Bidang Penerbitan 
Sertifikat Tanah Terhadap

Kepuasan Masyarakat Pada

Kantor Badan Pertanahan

Nasional Kota Makassar." Jurnal

Ilmiah Ilmu Administrasi Publik 4(1): 65-83.

Penanaman, Perizinan, and Verena Grescentia T. 2019. "2685-8096 II p-Issn 2686-027." 1(2): 66-80.

Retnowati, E. 2012. "Keterbukaan Informasi Publik." : 54-61.

Sjoraida, Diah Fatma. 2015. "Implementasi Kebijakan Keterbukaan Informasi Publik Pada Pemerintah Provinsi Jawa Barat." Sosiohumaniora 17(3): 204.

Susila Wibawa, Kadek Cahya. 2019. "Urgensi Keterbukaan Informasi Dalam Pelayanan Publik Sebagai Upaya Mewujudkan Tata Kelola Pemerintahan Yang Baik." Administrative Law and Governance Journal 2(2): 21834.

Tullah, Rahmat, and Muhammad Iqbal Hanafri. 2014. "Evaluasi Penerapan Sistem Informasi Pada Politeknik LP3I Jakarta Dengan Metode Pieces." Jurnal Sisfotek Global.

Tunggul, Adi Mora, Rizal Isnanto, and Oky Dwi Nurhayati. 2016. "Evaluasi Kinerja Organisasi Publik Dengan Menggunakan Pendekatan Balanced Scorecard Dan Analytic Network Process." Jurnal Sistem Informasi Bisnis 6(2): 124.

Wanprala, Coni, Isnaini Muallidin, and Dewi Sekar Kencono. 2020. "Kualitas Layanan Keterbukaan Informasi Publik Berbasis Webportal Pada Pejabat Pengelola Informasi dan Dokumentasi (PPID) Kabupaten
Sleman Tahun 2019." Kybernan: Jurnal Studi Kepemerintahan.

Wardana, Data, and Geovani Meiwanda. 2017. "Reformasi Birokrasi Menuju Indonesia Baru, Bersih Dan Bermartabat." Pemerintahan, Politik dan Birokrasi 3(April): 334.

West, Damian, and Deborah Blackman. 2015. "Performance Management in the Public Sector." Australian Journal of Public Administration.

Zulaikha, Zulaikha, and Agni Istighfar Paribrata. 2017. "Implementasi Kebijakan Keterbukaan Informasi Publik Di Jawa Timur Tahun 2016." Jurnal Studi Komunikasi (Indonesian Journal of Communications Studies). 